\title{
Purification of firefighting water containing a fluorinated surfactant by reverse osmosis coupled to electrocoagulation-filtration
}

\author{
Clément Baudequin ${ }^{\mathrm{a}}$, Estelle Couallier ${ }^{\mathrm{a}, *}$, Mohammed Rakib $^{\mathrm{a}}$, Isabelle \\ Deguerry $^{\mathrm{b}}$, Romain Severac $^{\mathrm{b}}$, Martial Pabon ${ }^{\mathrm{c}}$ \\ ${ }^{a}$ Laboratoire de Génie des Procédés et matériaux, École Centrale Paris, Grande Voie des \\ Vignes, 92295 Châtenay-Malabry, France \\ ${ }^{b}$ DuPont de Nemours France SAS, allée de Chantereine, F-78711 Mantes la Ville, France \\ ${ }^{c}$ DuPont de Nemours International, 2 Chemin du Pavillon, 1218 Geneva, Switzerland
}

\begin{abstract}
Extinguishments of large scale solvent fires produce large amounts of water that may contain various fluorinated surfactants depending on the type of firefighting foam used. Due to their chemical nature, fluorinated parts of fluorinated compounds are highly resistant to biochemical and advanced oxidation processes. Therefore the current treatment for the degradation of fluorinated surfactant from water used in fire extinguishment is high temperature incineration of the water in halogen resistant incinerators. This paper aims to propose a process for purifying firefighting water containing fluorinated surfactants.

Pilot firefighting waters resulting from heptane fire extinguishment with firefighting foam containing a fluorinated surfactant were produced. Suspended matter was estimated on the basis of turbidity measurement and fluorinated surfactant concentration was determined by high performance liquid chromatography at the laboratory and some samples were analyzed by solid phase
\end{abstract}

\footnotetext{
*Corresponding author

Email address: estelle.couallier@ecp.fr (Estelle Couallier) 
extraction and liquid chromatography coupled with mass spectrometry by the Norwegian Institute for Air Research (NILU). Pilot firefighting waters were not suitable for direct membrane processes because of high fouling, hence electrocoagulation and filtration were required. Electrocoagulation with aluminium electrodes at a charge loading of $600 C L^{-1}$ followed by filtration were found sufficient to remove turbidity from pilot firefighting waters. Fluorinated surfactant removal was $71-77 \%$ and was not significantly increased by higher charge loading. Floc separation in bulk solution was achieved by filtration. Reverse osmosis of pretreated pilot firefighting water and concentrated model solutions of pretreated firefighting water were studied and though flux decline was observed, measured retention rates were $99.94-99.97 \%$, with permeate concentrations down to $10-16 \mu g L^{-1}$ of fluorinated surfactant at the laboratory scale. The concentrate from reverse osmosis could be recycled in electrocoagulation-filtration. Experimental results indicated that electrocoagulation and filtration followed by reverse osmosis efficiently treated the water from fire extinguishment, which enables a further scale-up work.

Keywords: Fluorinated surfactant, Electrocoagulation, Filtration, Reverse osmosis, Fire fighting, Water Treatment

\section{Introduction}

Large class B fires - i.e. polar or non polar burning liquids - can occur in places like refineries, airports or chemical plants. Such fires can be put out with the help of fire fighting foams prepared from specific aqueous formulations, called foam concentrates diluted in water to 1-6\% and applied with a nozzle under the form of foam. The very low apparent foam density allows it to be deposited at the surface of burning liquids. The foam spreads at the surface generating an aqueous film which reduces the emission of flammable vapors. Foam concentrates usually contain hydrocarbon surfactants or protein hydrolysates (synthetic or proteinic concentrate), and one or several 
fluorinated surfactants in case of high performance foam concentrates.

During industrial solvent fires large amounts of water and foam are used: several cubic meters per minute during several days. Resulting water consists of either water from the foam and water used to protect equipment and persons from the heat of the fire. Therefore its composition is expected to be somehow close to diluted foaming solution. In the emergency of a large fire event, every available foam concentrates are used: synthetic or proteinic concentrates. If alcohol resistant foam was used, hydrocarbon and fluorinated water soluble polymers might also be present. Hence this water may contain protein hydrolysates, various hydrocarbon and fluorinated surfactants and polymers in addition to burned solvent, particles and soot, with volume up to $750 \mathrm{~m}^{3}$ of foam concentrate [1]. This leads to an estimation of $25.000 \mathrm{~m}^{3}$ of water on the basis of a $3 \%$ dilution. The present work aims at identifying the most appropriate technique to purify the water used during fire extinguishment. The final unit has to be mobile to be used on many different sites to absorb the fix cost of the equipment. Not only the resulting techniques are expected to be sustainable in terms of water recovery, energy and material consumption versus straight incineration, they also have to be easily scaled up and dimensioned to extract fluorinated surfactants from water at a rate of 4,000-10,000 $\mathrm{m}^{3}$ in 3-6 months.

\subsection{Hydrocarbon and fluorinated surfactants}

A surfactant molecule contains at least one hydrophilic group constituted of ionized or polar assembly and a hydrophobic part constituted of carbonated chains. Due to their amphiphilic nature, surfactants adsorb preferentially at interfaces, and form aggregates called micelles when reaching critical micelle concentration (CMC). For sufficiently low monomer concentration, most of the molecules in the solution are isolated. Once the concentration approaches the $\mathrm{CMC}$, addition of solute molecules results in the formation of aggregates while living monomer concentration more or less unchanged at the $\mathrm{CMC}$ 
value [2].

Fluorinated chains confer to fluorinated surfactants particular properties in regard of hydrocarbon surfactants. With the electronegativity of fluorine replacing some hydrogen atoms, the polarity of the $\mathrm{C}-\mathrm{F}$ bound is reversed and the binding stronger compared to $\mathrm{C}-\mathrm{H}$ bound. So, chemical and thermal resistance of fluorinated compounds are highly increased compared to hydrocarbon ones. Fluorinated compounds like poly(tetrafluoroethylene) (PTFE) show oil and water repellence and are used in surface treatment for these properties. Compared to hydrocarbon ones, fluorinated surfactants have a lower CMC, they have a bigger influence on water surface tension even at low concentration, and allow reaching surface tension as low as $15-20 \mathrm{mN} . \mathrm{m}^{-1}$ at $20^{\circ} \mathrm{C}$ [3]. Fluorinated surfactants are most commonly used as photolithographic chemicals in semiconductor industry, as emulsifiers in polymerization of fluoropolymers and as additive in high performance fire-fighting foams.

\subsection{Treatment processes for water containing fluorinated surfactants}

Most of the studies about treatment of water containing fluorinated surfactants focus mainly on anionic fluorinated surfactants like perfluorooctane sulfonate (PFOS), perfluorooctanoic acid (PFOA) and a few others, which are different compounds from the fluorinated surfactants used in firefighting foams and considered in the present paper. Due to its particular nature, carbon-fluorine bond is highly resistant to biochemical degradation [4] and advanced oxidation processes [5]. Fluorinated surfactants can be incinerated at high temperature in halogen resistant incinerators, but water incineration is not economically acceptable hence these surfactants have to be extracted from the water by physico-chemical processes, concentrated and then sent to incineration.

Adsorption of anionic fluorinated surfactants on several adsorbents has been studied 6, 7and powder activated carbon seemed to be the most interesting adsorbent. Adsorption of fluorinated surfactant potentially present in 
firefighting water was studied on activated carbon [3], showing interesting results for the extraction of fluorinated surfactants but pinpointing the need of improvements regarding the cost in use and the high sensitivity (rapid saturation) to polymers and proteins potentially present in the fire fighting water.

\section{Membrane processes}

Another way to remove fluorinated surfactants from water is to use membrane processes, which principle is to separate components of a solution thanks to a membrane and pressure as driving force. The membrane is a porous separator which lets small compounds like water go across in the permeate, whereas it retains larger molecules or particles in the retentate. Different membrane processes exist depending on the size of the molecules to separate. Among others, nanofiltration (NF) is used for molecules around $1 \mathrm{~nm}$ and reverse osmosis (RO) for smaller molecules or salts. The rejection is represented by the retention rate:

$$
R=1-\frac{C_{P}}{C_{R}}
$$

with $C_{P}$ the concentration in the permeate, $C_{R}$ the concentration in the retentate. The volume reduction ratio represents the retentate volume reduction due to extraction of permeate:

$$
V R R=\frac{V_{0}}{V_{R}}
$$

with $V R R$ the volume reduction ratio, $V_{0}$ the initial feed volume and $V_{R}$ the final retentate volume.

Steinle-Darling and Reinhard used polyamide-based nanofiltration membranes to study the retention of various fluorinated surfactants [8]. Charged compounds were found to be efficiently retained with retention rates higher than 
$95 \%$ on the contrary to nonionic perfluorooctane sulfonamide that appeared to permeate over long periods. Perfluorooctane sulfonamide does not have the same chemistry as the amphoteric fluorinated surfactant (Capstone $\mathbb{R}$ ) 1157) used in the present study, hence the same behavior in membrane processes cannot be expected. Membranes exhibited some fluorinated surfactant adsorption that resisted to pure water washing. Tang et al. [9, 10] studied the rejection of PFOS with various NF and RO membranes. The rejection efficiencies for the RO membranes were $>99 \%$, and those for the NF membranes ranged from 90 to $99 \%$.

\section{Coagulation theory}

In the course of the present project, preliminary filter experiments as pretreatment showed a dramatic fouling on various filters including membrane filters (microfiltration and ultrafiltration) by water used during fire extinguishment, pinpointing the need of a coagulation method to remove suspended matter from these waters. Coagulation-flocculation is a classical pretreatment in wastewater treatment plants, removing various particles and dissolved organic matter. Coagulant can be aluminium or ferric salts (aluminium sulfate, ferric chloride, ferric sulfate, polyaluminium chloride), or polyelectrolytes. It is commonly admitted that coagulation occurs according to two mechanisms: charge neutralization and sweep flocculation [11]. Once coagulated, the removal of previously suspended matter becomes easier by settling or filtering. As mentioned earlier, the final unit we consider here has to be mobile so processes have to fit the constraints of compactness, material and chemical input minimization, automatization and continuous operation in addition to efficiency. Hence electrocoagulation, another coagulation method, was chosen.

\section{Electrocoagulation}

Coagulants in electrocoagulation, Fe or Al salts generally, are electrochemically introduced by in situ dissolution of a metallic anode. When aluminium 
anode is used, the following reactions take place $[12,13]$ :

At the cathode:

$$
3 \mathrm{H}_{2} \mathrm{O}+3 e^{-} \rightleftharpoons \frac{3}{2} \mathrm{H}_{2}+3 \mathrm{OH}^{-}
$$

At the aluminium anode:

$$
A l_{(s)} \rightleftharpoons A l_{(a q)}^{3+}+3 e^{-}
$$

At high pH, in case of aluminium cathode, cathodic dissolution can occur [14]:

$$
2 \mathrm{Al}+6 \mathrm{H}_{2} \mathrm{O}+2 \mathrm{OH}^{-} \rightleftharpoons 2 \mathrm{Al}(\mathrm{OH})_{4}^{-}+3 \mathrm{H}_{2}
$$

$\mathrm{Al}^{3+}$ can react with $\mathrm{OH}^{-}$produced in equation 3 to form the following hydroxides [15, 11]:

$$
A l(O H)_{j}^{3-j}+O H^{-} \rightleftharpoons A l(O H)_{j+1}^{2-j} \text { for } j=0 \text { to } 3
$$

In addition, formation of many polymeric aluminium salts over a wide $\mathrm{pH}$ range has been proposed [16]. Aluminium hydroxide species finally precipitate according to complex kinetics to form amorphous $\mathrm{Al}(\mathrm{OH})_{3}[17,18]$ :

$$
A l_{n}(O H)_{3 n-1}^{+}+O H^{-} \rightleftharpoons n A l(O H)_{3 \text { amorphous }}
$$

Active species in electrocoagulation are those which enable charge neutralization, sweep flocculation, adsorption and precipitation. These species have been reported to be charged hydroxo cationic complexes and amorphous aluminium hydroxide $[11,17,18]$. Electrocoagulation with aluminium electrodes was reported to show the best efficiency between $p H 6$ and 9 [19], which corresponds to the existence zone of amorphous $\mathrm{Al}(\mathrm{OH})_{3}$ (Fig. 1). Addition of electrolyte in electrocoagulation has been reported to improve the efficiency 
of the process 20 . However this point will not be investigated because of the compactness and autonomy constraints.

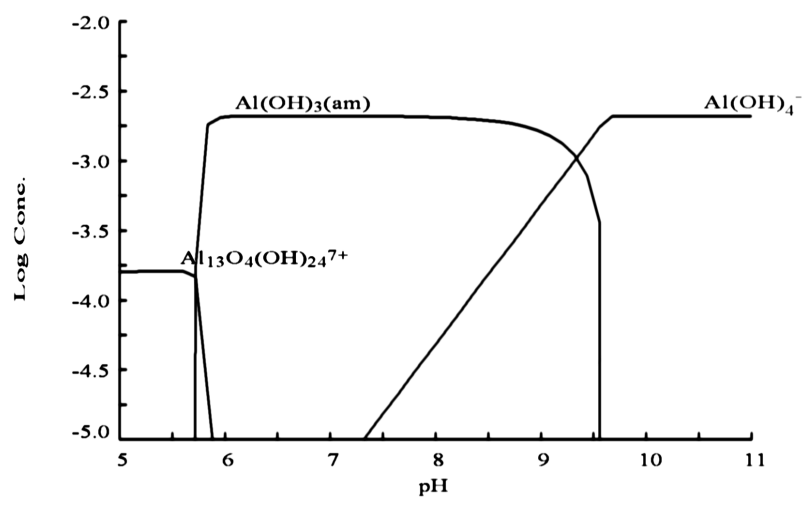

Figure 1: Aluminium speciation in aqueous solution, obtained by Hydra/Medusa software, for aqueous solution containing $2.1 \mathrm{mM}$ of $A l^{3+}$, assuming amorphous aluminium hydroxide as the only possible solid species.

The floc produced in solution during electrocoagulation is subject to settling and electroflotation. Physical separation of the floc can also be achieved by hydrocycloning, centrifuging, flotation, dissolved air flotation and filtration [21]. Determination of the most appropriate technique for floc segregation at scale after electrocoagulation will be covered by a further scale-up work. Resulting sludges are intended to be burnt in halogen resistant high temperature incinerators. Electrocoagulation was reported to be high efficient, compact, relatively low cost, completely automatizable and electrocoagulation reactors range from basic to very sophisticated design [13].

The purpose of this paper is:

- the optimization of electrocoagulation and filtration as a pretreatment process for pilot firefighting waters modeling the composition of water used during fire extinguishment 
- the assessment of the feasibility of reverse osmosis as a treatment process for the pretreated firefighting water, aiming $100 \mu \mathrm{g} \mathrm{L}^{-1}$ in the purified water

\section{Material and methods}

\subsection{Pilot firefighting waters production}

Pilot firefighting waters representing water from the extinction of non-polar solvent fire were generated by extinguishment of $0.25 \mathrm{~m}^{2}(2 \mathrm{~L})$ heptane fires by $3 \%$ firefighting foam which components are listed in table 1. After each fire extinguishment, resulting water and burned heptane were recovered and the device was washed with tap water. Mixing washing water with the previous mixture modeled the extra use of water by firefighting men during fire events. The resulting liquid presented two phases: an upper organic phase containing heptane and the aqueous phase, with an heptane-in water emulsion at the interface. Pilot firefighting waters (PFW) were produced by discarding the organic phase and the emulsion, keeping only the aqueous phase. Several fire extinguishments led to the production of PFW 1, 2 and 3.

\subsection{Analysis}

\subsubsection{Turbidity and surface tension measurements}

Turbidity measurements in nephelometric turbidity units $(N T U)$ were achieved with a HACH $2100 \mathrm{AN}$ turbidimeter. Turbidity is due to suspended matter that scatters light. It represents the amount of fine matter responsible for the cloudiness of the sample [22]. Surface tension measurements were done on a Lauda tensiometer, with the stirrup method.

\subsubsection{Fluorinated surfactant liquid chromatography}

Only the major compound of the Forafac $1157 \mathrm{~N}$ fraction was considered. Sample homogenization was achieved in $60 \mathrm{~mL}$ glass vials, using a Heidolph 
Topmix 94323 vortex. High performance liquid chromatography (HPLC) measurements were performed with an analytical system composed of a Knauer K-501 HPLC pump (Eurosep Instruments), a Rheodyne valve with a $40 \mu \mathrm{L}$ injection loop, an Eclipse Zorbax XDB-C8 analytical column (Agilent Technologies, $4.6 \mathrm{~mm} 150 \mathrm{~mm}, 5 \mu \mathrm{m}$ particle size), a column oven at $35^{\circ} \mathrm{C}$ and the mobile phase was methanol:water $70 \%$ vol. at a $0.5 \mathrm{~mL} \mathrm{~min}^{-1}$ isocratic flow rate. The detector was an ESA Evaporative Light-Scattering Detector (ELSD, Chromachem, Eurosep Instrument), attenuation was 2, nitrogen pressure was 1.5 bar, nebulization and evaporation temperatures were 50 and $70^{\circ} \mathrm{C}$ respectively, data acquisition was done with Azur software. Simultaneous resolution of the anionic, non ionic, amphoteric hydrocarbon surfactants and fluorinated surfactant could not be achieved with the aforementioned mobile phase, which was intended to resolve the fluorinated surfactant only, with a limit of detection of $1.4 \mathrm{mg} \mathrm{L}^{-1}$. The calibrating curve was established from 4 to $500 \mathrm{mg} \mathrm{L}^{-1}$, the error was below $5 \%$, every analysis were done twice. Samples with a turbidity superior to $1 N T U$ were filtered on Roth $0.45 \mu \mathrm{m}$ PVDF syringe filters. After PVDF filtration fluorinated surfactant recovery rate was $90 \%$.

To detect fluorinated surfactant concentration below the detection limit a sample concentration method was set up. The method consisted of 1-volume reduction by evaporation, 2-surfactants redissolution by a $70 \%$ methanol recovery solution. Accurate volumes near $60 \mathrm{~mL}$ of dilute solutions were evaporated to dry at $90^{\circ} \mathrm{C}$ in glass vials. After cooling at room temperature $3 \mathrm{~mL}$ of recovery solution were added to the vials before vortex agitation. The resulting solutions contained concentrated surfactants that allowed analysis down to $0.2 \mathrm{mg} \mathrm{L}^{-1}$, with an average recovery rate of $80 \%$. Samples of lower concentration were analyzed by solid phase extraction (SPE) and liquid chromatography coupled with mass spectrometry (LC-MS) by the Norwegian Institute for Air Research (NILU). NILU's laboratories are accredited according to NS-EN ISO/IEC 17025. 


\subsubsection{Aluminium atomic absorption spectrometry}

Aluminium quantification was done by atomic absorption with a Varian SpectrAA 220 atomic absorption spectrometer, with a reducing flame of acetylene fuel and nitrous oxide support, data was gathered and processed on a computer by the SpectrAA 2202.10 software. Wavelength was set to $232 \mathrm{~nm}$ and $2 g L^{-1}$ of potassium chloride were added to the sample in order to minimize aluminium ionization in the flame, samples were acidified with $\mathrm{HNO}_{3}$. Detection ranged from 0.5 to $250 \mathrm{mg} \mathrm{L}^{-1}$, the error was below $5 \%$.

\subsection{Electrocoagulation and filtration}

Two different cells were used to carry out electrocoagulation experiments. EC1 cell had a volume from 0.5 to $2 L$, reversible aluminium electrodes, and an anode surface of $350 \mathrm{~cm}^{2}$. EC2 cell had a volume of 3 to $5 \mathrm{~L}, 815 \mathrm{~cm}^{2}$ of aluminium anode and stainless steel cathode. Suspended floc was removed by filter press dead-end filtration, achieved on a device with a filtration surface of $50 \mathrm{~cm}^{2}$ supplied by Choquenet, using a Masterflex peristaltic pump (Cole Parmer Instruments). At the laboratory scale, the volume of electrocoagulated pilot firefighting water was not sufficient to enable the formation of a cake as a filtering media. Hence the filter was coated with $2.4 \mathrm{~mm}$ of $\mathrm{CaCO}_{3}$ before each filtration experiment.

\subsection{Reverse osmosis}

Reverse osmosis experiments were done on a Millipore ProScale nanofiltration and reverse osmosis pilot, with a SG1821C-28D reverse osmosis spiral membrane supplied by Osmonics, with a thin film polyamide active phase and a surface area of $0.37 \mathrm{~m}^{2}$. Pilot had a dead volume of $0.8 \mathrm{~L}$, superficial velocity was $84.10^{-3} \mathrm{~ms}^{-1}$ and operating pressure was $20 \mathrm{bar}$, all permeability measurements were scaled to $25^{\circ} \mathrm{C}$. The membrane permeability was $2 L h^{-1} m^{-2} b a r^{-1}$ for pure water. 


\subsubsection{Model pretreated firefighting water composition}

Reverse osmosis was used on filtered electrocoagulated pilot firefighting water and on a model pretreated firefighting water which represented a foaming solution diluted to reach a fluorinated surfactant concentration near $20 \mathrm{mg} \mathrm{L}^{-1}$. In order to simulate high concentration by reverse osmosis, $3 L$ of initial model pretreated firefighting water were artificially concentrated by successive addings of $500 \mathrm{~mL}$ solution containing the necessary amounts to double the concentration of each compound. The resulting compositions are listed in table 2 .

\section{Results and discussion}

\subsection{Pilot firefighting waters}

Turbidity and fluorinated surfactant concentration of the three pilot firefighting water used in this work are presented in table 3. Fluorinated surfactant concentration ranged from 94 to $144 \mathrm{mg} \mathrm{L}^{-1}$. Turbidities of PFW1 and PFW2 - 27 and 30 NTU respectively, were very near whereas PFW3 showed a 70 NTU turbidity. This extra turbidity was due to heptane-in-water emulsion present in PFW3.

\subsection{Electrocoagulation}

\section{Description}

During every pilot firefighting water electrocoagulation experiments the same steps were observed: (i) white floc production at the anode; (ii) increasing of the bulk solution cloudiness, coagulation of suspended matter and electroflotation of a dark gray floc; (iii) decreasing of bulk solution cloudiness and gradual floc color shift from dark gray to white. Turbidities in bulk solution and $0.45 \mathrm{\mu m}$ filtered bulk solution were measured during the electrocoagulation of $3 L$ of PFW1 at $2 A$ in EC2 cell (Fig. 2). During the first step the turbidity of the bulk solution increased from 30 to $52 \mathrm{NTU}$ due 
to floc formation, during the second step it slightly decreased to $42 \mathrm{NTU}$ while suspended matter was removed by electrocoagulation-electroflotation. During the last step, even if the solution looked clearer, turbidity increased again probably due to floc accumulation in absence of coagulable suspended matter.

At the end of the experiment the electroflotated floc at the surface formed three layers with blurred boundaries. From top to bottom (chronological order), the layers were white, black and white, indicating that all electrocoagulable suspended matter was removed during the second step. Turbidity of the bulk solution filtered with $0.45 \mu \mathrm{m}$ PVDF syringe filter was $1 \mathrm{NTU}$ since $15 \mathrm{~min}$, the time at which white floc formed again. Hence the necessary time of electrocoagulation to remove suspended matter could be visually estimated as the time needed to see white floc again, here $15 \mathrm{~min}$ corresponding to a charge loading per volume of $600 C L^{-1}$ in EC2 cell.

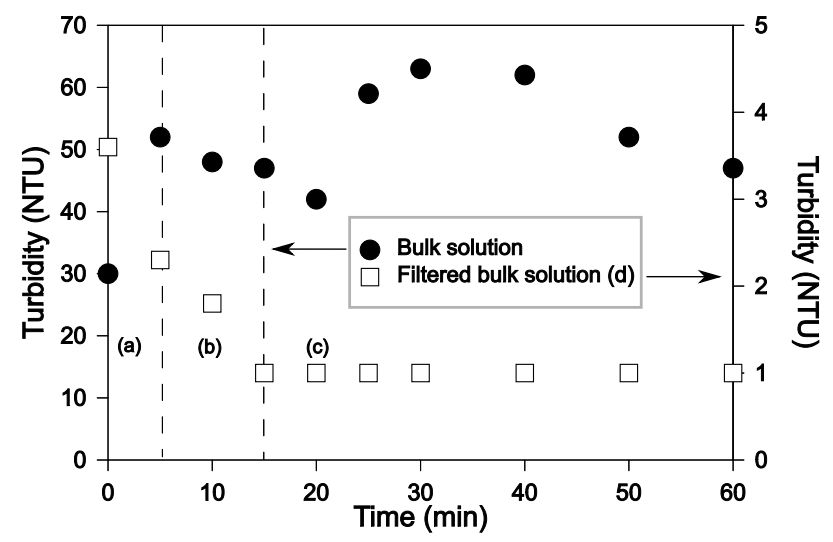

Figure 2: Turbidity during electrocoagulation of $3 \mathrm{~L}$ of PFW1, 2 A, in EC2 cell. (a): White floc electroflotation, (b): dark gray floc electroflotation, (c): gradual floc color shift from dark gray to white, (d): filtration done with $0.45 \mu m$ PVDF syringe filters.

Determination of the minimal charge loading per volume for pretreatment

Electrocoagulation experiments with PFW2 were done at different current densities and different pilot firefighting water volume to estimate minimal 
pretreatment times and charge loading per volume visually (Tab. 4). Minimal time seemed to depend on the volume of the solution and on the charge loading passing through it. However, the estimated minimal needed charge loadings per volume varied, with an average of $540 C L^{-1}$. These differences could be related to the difficulty to estimate precisely when the white floc comes back, as it showed up in the bulk solution before complete electroflotation of the electrocoagulated suspended matter. After $0.45 \mu \mathrm{m}$ PVDF syringe filtration, all solution had a turbidity of less than 1 NTU.

\section{Action of electrocoagulation on fluorinated surfactant concentration}

Fluorinated surfactant concentrations of some electrocoagulated PFW2 solution were measured by HPLC analysis after filtration on $0.45 \mu \mathrm{m}$ PVDF syringe filters (Tab. 5). A charge loading of about $600 C L^{-1}$ gave fluorinated surfactant concentration near $38 \mathrm{mg} \mathrm{L}^{-1}$ (71\% removal). Fluorinated surfactant removal seemed to be directly related to total charge loading as long as pH did not exceed 8 (Tab. 5). Above $\mathrm{pH} 9.5$ the prominent species among total aluminium becomes $\mathrm{Al}(\mathrm{OH})_{4}^{-}$(Fig. 1), which is soluble and less efficient for electrocoagulation [23]. A too high $\mathrm{pH}$ seemed to be the reason why electrocoagulation was less efficient on fluorinated surfactant removal at

$3528 C L^{-1}$ than at $2352 C L^{-1}$, indicating in this case the need of $\mathrm{pH}$ control to maintain the efficiency of the process.

\section{Aluminium concentration during electrocoagulation}

Aluminium was quantified by atomic absorption in PFW2 samples electrocoagulated in EC1 cell. Atomic absorption was done on two types of $0.45 \mu \mathrm{m}$ PVDF syringe filtered samples: the bulk solution-dissolved aluminium, and the whole solution mixed with its floc acidified with $\mathrm{HCl} 37 \%$ to $\mathrm{pH}$ 1-total aluminium. The results are listed in table 5. Dissolved aluminium concentrations were estimated around $1 \mathrm{mg} \mathrm{L}^{-1}$ independently of the charge loading as long as $\mathrm{pH}$ did not exceed 8. For high charge loadings, as $\mathrm{pH}$ were 8.2 and 
10.3, dissolved aluminium concentrations were 2.6 (estimated value) and 29 $m g L^{-1}$ respectively. Aluminium current efficiencies were calculated on the basis of the following equation:

$$
\eta=\frac{3 n_{A l} F}{i t}
$$

with $n_{A l}$ the mole number of aluminium, $\eta$ the current efficiency, $F=$ $96500 \mathrm{C} \mathrm{mol}^{-1}$ the Faraday constant, $i$ the current intensity in $\mathrm{A}$ and $t$ the time of electrolysis in $s$. Aluminium current efficiencies all exceeded $100 \%$ in EC1 cell with both electrodes made of aluminium. This can be explained by the cathodic chemical dissolution of aluminium by $\mathrm{OH}^{-}$(Eq. 5) produced by water reduction [14].

For the experiments done in the EC1 cell, the lower the current density, the higher the minimal charge loading per volume (Tab. 4), which high limit seemed to approach $600 C L^{-1}$, the minimal loading charge obtained with the stainless steel cathode of EC2 cell. This was consistent with a higher aluminium cathodic dissolution for higher current densities [14]. Aluminium dosing more than charge loading, and aluminium speciation seemed to be the key parameters in electrocoagulation of our pilot firefighting waters.

Removal of heptane-in-water emulsion from pilot firefighting water by electrocoagulation

Electrocoagulation was reported to be efficient to treat water containing oilin-water emulsion $[24,25,26]$. As the water used during fire extinguishment may contain such emulsions, an experiment was done with PFW3. This pilot firefighting water presented a turbidity of $70 \mathrm{NTU}$ whereas the turbidity of emulsion-free firefighting water was $30 N T U$. Hence this difference of turbidity could be attributed to the emulsion. $3 \mathrm{~L}$ PFW3 were electrocoagulated at $1 \mathrm{~A}$. Turbidity of the bulk solution was measured before and after $0.45 \mathrm{\mu m}$ PVDF filter syringe filtration (Fig. 3). Initial turbidity increase seemed to 
be due by floc formation and its further decrease to floc sedimentation and electroflotation. At the beginning of the experiment, filtration only removed about 20 NTU but after 30 min, turbidity after filtration was near 1 NTU. Hence a $600 C L^{-1}$ loading charge per volume was sufficient to remove the turbidity due to heptane-in-water emulsion in addition to the one due to suspended matter, providing a clear pretreated firefighting water. However, the presence of heptane-in-water emulsion decreased the efficiency of fluorinated surfactant removal, which concentration was $100 \mathrm{mg} \mathrm{L}^{-1}$ after $30 \mathrm{~min}-600$ $C L^{-1}$ instead of $30-40 \mathrm{mg} \mathrm{L} L^{-1}$ for emulsion-free pilot firefighting water.

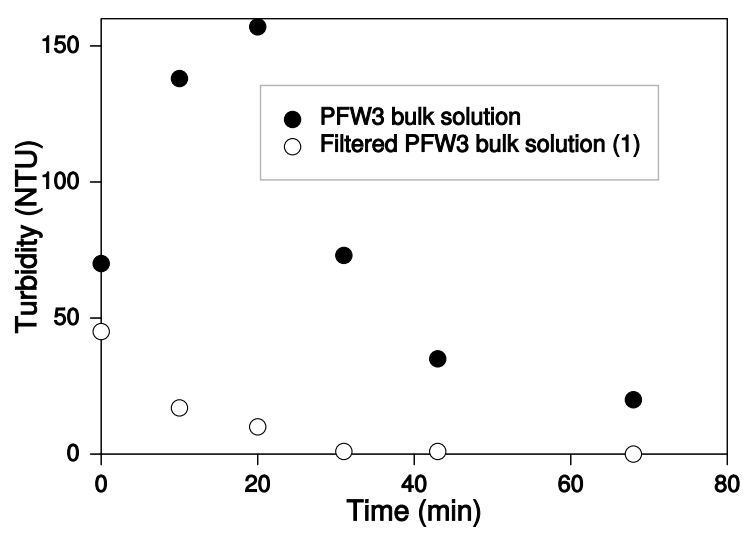

Figure 3: Turbidity during electrocoagulation of PFW3, $3 \mathrm{~L}, 1 \mathrm{~A}$. (1): filtration done with $0.45 \mu \mathrm{m}$ PVDF syringe filters.

\subsection{Pilot firefighting water pretreatment by electrocoagulation and filtration}

Foaming base solutions made of water and foam components had turbidities near $2 N T U$ before being used for firefighting. Thus target turbidity for pretreated pilot firefighting water was chosen as $\leq 2 N T U$. The needed electrocoagulation charge loading to reach this turbidity level in pilot firefighting water after $0.45 \mu \mathrm{m}$ syringe filtration was found to be $600 C \mathrm{~L}^{-1}$. Turbidity after direct press filtration was not satisfying because at the laboratory scale, electrocoagulated PFW2 bulk solution did not contain enough floc to form 
a filtering cake. Therefore filter press was coated with $2.4 \mathrm{~mm}$ of $\mathrm{CaCO}_{3}$ to fasten the formation of the filtering media on the filter.

Pretreated PFW2 was produced by electrocoagulation of $4 L$ of PFW2 in EC2 cell, $40 \mathrm{~min}$ at $1 \mathrm{~A}$. The filter press probe was then introduced in the cell below the layer of electroflotated floc, to pump only the bulk solution which contained $1.126 \mathrm{~g} \mathrm{~L}^{-1}$ of dry matter. The volume needed to form an efficient floc filtering media on the coated filter was $750 \mathrm{~mL}$. Hence the first $750 \mathrm{~mL}$ were discarded, on the contrary to the following clear filtrate. Filtration showed a cake filtration profile (Fig. 4) with a corresponding floc specific resistance of $2.610^{12} \mathrm{~m} \mathrm{~kg}^{-1}$. The use of a filtration adjuvent could facilitate the floc filtration if needed. The operation was done twice and both resulting filtrates were mixed to get $6 \mathrm{~L}$ of pretreated PFW2 (PPFW2) at $p H 6.9$, showing a turbidity of $0.4 N T U$, a fluorinated surfactant concentration of $31 \mathrm{mg} \mathrm{L}^{-1}$ (77\% removal), $0.837 \mathrm{~g} \mathrm{~L}^{-1}$ of dry matter and non-detected aluminium concentration. Electrocoagulation and filtration of the pilot firefighting water enabled the production of a pretreated pilot firefighting water suitable for membrane processes.

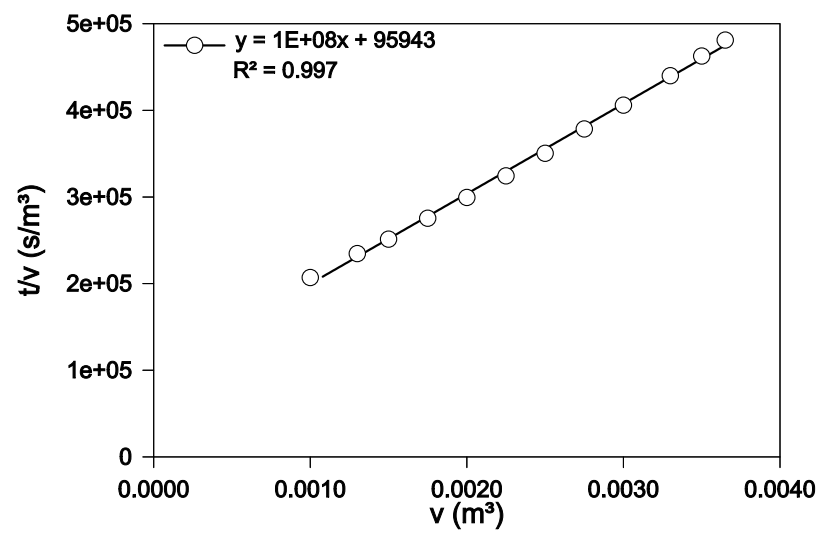

Figure $4: \mathrm{t} / \mathrm{v}$ versus $\mathrm{v}$ during filter press of pretreated pilot firefighting water bulk solution, with $\mathrm{v}$ : the permeate volume and $\mathrm{t}$ the time of filtration. 


\subsection{Reverse osmosis}

\subsubsection{Reverse osmosis of pretreated pilot firefighting water}

Reverse osmosis was used to treat $5 \mathrm{~L}$ of pretreated pilot firefighting water. The experiment consisted of successively $15 \mathrm{~min}$ of full recycle, extraction of $2 \mathrm{~L}$ of permeate, $20 \mathrm{~min}$ of full recycle and extraction of $1.7 \mathrm{~L}$ of permeate. Results are presented in table 6 . No surfactants were detected with the HPLC analytic system in any permeate and surface tension were 72.4 and $72.2 \mathrm{mN} \mathrm{m}^{-1}$ at $25.0^{\circ} \mathrm{C}$ for the first and the second permeate respectively, very near demineralized water's that was $71.4 \mathrm{mN} \mathrm{m}^{-1}$ at $24.9^{\circ} \mathrm{C}$. According to additional analysis performed by the Norwegian Institute for Air Research, fluorinated surfactant concentration in permeates were 10.47 and $16.39 \mu \mathrm{g} \mathrm{L}^{-1}$, giving apparent retention rates of $99.97 \%$ and $99.96 \%$ for the first and second permeates respectively. Mass balance showed some missing fluorinated surfactant in the retentate, assumed to be adsorbed on the membrane.

\subsubsection{Reverse osmosis of synthetic pretreated firefighting water}

Reverse osmosis was done on PPFW2 until a volume reduction rate of 2.8 but the study of reverse osmosis at volume reduction rates near 20 would have required more than the whole available pilot firefighting water. Hence the study of pretreated pilot firefighting water concentration with reverse osmosis was done by artificial concentration of the model pretreated firefighting water by successive addings (Tab. 2), in full recycle mode. After each adding, flasks were rinsed three times with permeates and measurements were done $1 \mathrm{~h}$ later. During the experiment, membrane permeability decreased with increasing fluorinated surfactant concentration (Fig. 5). Though permeability decrease was strong, higher concentrations could lead to small permeability reductions. Considering concentrations, permeabilities were the same magnitude as previous experiments and near results from Tang et al [9] obtained 
with PFOS solutions and thin film composite polyamide ESPA RO membrane from Hydronautics.

No surfactants were detected in any permeates with the conventional HPLC method. The difference between expected and measured fluorinated surfactant concentrations in retentates showed that rather little amount of adsorbed fluorinated surfactant for low concentrations and was smaller than the measurements error for every higher concentration (Tab. 7). Relative adsorption seemed to be limited at high concentrations, which could be explained by small micelle adsorption compared to monomer, limiting fluorinated surfactant losses even at high concentrations.

An additional reverse osmosis experiment with a retentate concentration of $470 \mathrm{mg} \mathrm{L} \mathrm{L}^{-1}$ was done to quantify fluorinated surfactant concentration in permeate with the evaporation method. After two hours of equilibrium, permeate concentration was $0.271 \mathrm{mg} \mathrm{L}^{-1}$, corresponding to a $99.94 \%$ retention rate, near results from 3.4.1. With the obtained retention rates, assuming the verification of retention rate stability over long periods, a retentate of $140 \mathrm{mg} \mathrm{L}^{-1}$ would give a permeate concentrations between 42 and $84 \mu \mathrm{g} \mathrm{L}^{-1}$. To reach lower concentrations, a final treatment process such as a second reverse osmosis or adsorption should be used. Considering the global process, concentrated retentate from reverse osmosis should be sent to electrocoagulation in order to remove the fluorinated surfactant from the system only via the floc separation, sending only sludge to incineration.

\section{Conclusion}

Early results of the design of a mobile post-treatment unit for the water used during fire extinguishment have been presented. Electrocoagulation at $600 C L^{-1}$ followed by filtration on a coated filter was an efficient pretreatment process, removing suspended matter and $77 \%$ of initial fluorinated surfactant. The successful removal of suspended matter made the pretreated 


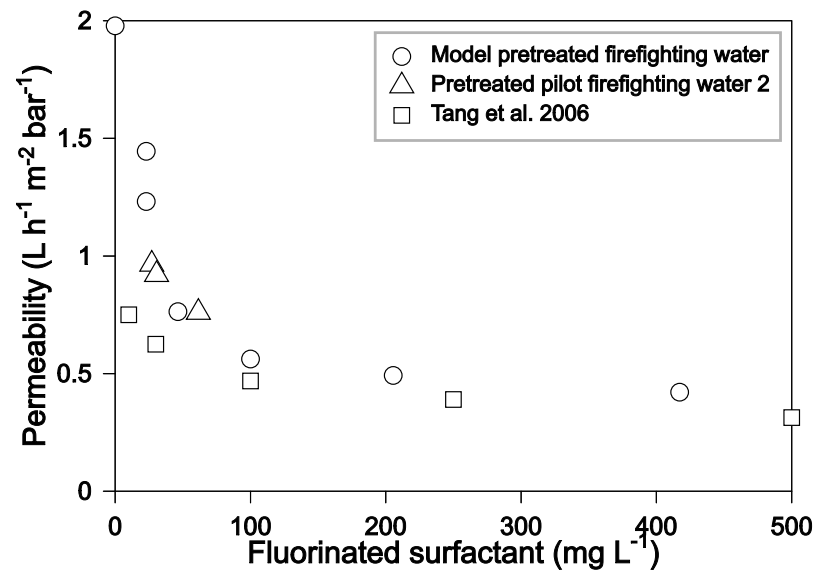

Figure 5: Permeability versus total fluorinated surfactant concentration in the system during reverse osmosis, 20 bar, 13.8 bar for Tang et al.

firefighting water relevant for reverse osmosis treatment. Reverse osmosis showed retention rates higher than $99.94 \%$, resulting in permeate concentrations down to $10-16 \mu \mathrm{g} \mathrm{L}^{-1}$ of fluorinated surfactant, which were below the

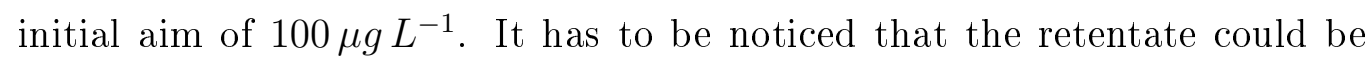
recycled in electrocoagulation. The next step of this project is the development of the required data to scale up the equipment, materials and energy consumption, input and output fluxes for a specific water treatment unit in order to treat firefighting water on significant volumes (several thousand $m^{3}$ ), with a residual fluorinated surfactant concentration below $100 \mu g L^{-1}$. This mobile unit would involve electrocoagulation, floc segregation and reverse osmosis which have been identified in the present study as appropriate techniques. Data generation work for the scale up will include an estimation of the soil generated through electrocoagulation as well as aluminium consumption. 
Table 1: Composition of the $3 \%$ foaming base used to generate pilot firefighting waters. Demineralized water represented $72.6 \%$, diethanolamine was added to reach $p H 7.5$. *: Commercial solutions.

\begin{tabular}{|c|c|c|c|c|}
\hline Compounds & $\begin{array}{c}\text { Name of } \\
\text { commercial } \\
\text { product }\end{array}$ & Company & $\begin{array}{l}\text { Mass } \\
\text { percentage of } \\
\text { the product in } \\
\text { the foaming } \\
\text { base }\end{array}$ & $\begin{array}{c}\text { Active } \\
\text { compounds } \\
\text { concentrations } \\
\left(m g L^{-1}\right)\end{array}$ \\
\hline $\begin{array}{l}\text { Dipropylene } \\
\text { glycol } \\
\text { methyl } \\
\text { ether }\end{array}$ & $\begin{array}{c}\text { Dowanol } \\
\text { DPM }\end{array}$ & $\begin{array}{l}\text { Dow } \\
\text { Chemi- } \\
\text { cals }\end{array}$ & $10 \%$ & 3000 \\
\hline $\begin{array}{l}\text { Sodium } \\
\text { octyl } \\
\text { sulfate }\end{array}$ & $\begin{array}{c}\text { Disponil } \\
\text { SOS } 842^{*}\end{array}$ & Cognis & $8 \%$ & 960 \\
\hline $\begin{array}{l}\text { Sodium } \\
\text { octyl and } \\
\text { hexyl pro- } \\
\text { pionate }\end{array}$ & $\begin{array}{l}\text { Rewoteric } \\
\text { AM VSF* }\end{array}$ & $\begin{array}{l}\text { Evonik } \\
\text { GmbH }\end{array}$ & $2.4 \%$ & 360 \\
\hline $\begin{array}{l}\text { Octyl } \\
\text { glucoside }\end{array}$ & $\begin{array}{c}\text { Simulsol } \\
\text { SL8* }\end{array}$ & Seppic & $2 \%$ & 240 \\
\hline $\begin{array}{l}\text { Amphoteric } \\
\text { fluori- } \\
\text { nated } \\
\text { surfactant } \\
\text { fraction }\end{array}$ & $\begin{array}{l}\text { Forafac } \\
1157 N^{*}\end{array}$ & DuPont & $5 \%$ & 405 \\
\hline
\end{tabular}


Table 2: Artificially concentrated model pilot firefighting water composition

\begin{tabular}{cccccc}
\hline Adding & 0 & 1 & 2 & 3 & 4 \\
\hline \hline Total volume $(L)$ & 3.8 & 4.3 & 4.8 & 5.3 & 5.8 \\
\hline $\begin{array}{c}\text { Diethylene glycol butyl ether } \\
\left(m g L^{-1}\right)\end{array}$ & 270 & 562 & 1122 & 2258 & 4561 \\
\hline Sodium octyl sulfate $\left(m g L^{-1}\right)$ & 87 & 175 & 357 & 734 & 1476 \\
\hline $\begin{array}{c}\text { Sodium octyl and hexyl } \\
\text { propionate }\left(m g L^{-1}\right)\end{array}$ & 20 & 43 & 85 & 127 & 220 \\
\hline Octyl glucoside $\left(m g L^{-1}\right)$ & 20 & 43 & 90 & 185 & 355 \\
\hline $\begin{array}{c}\text { Fluorinated surfactant } \\
\text { concentration }\left(m g L^{-1}\right)\end{array}$ & 23 & 46 & 100 & 205 & 417 \\
\hline
\end{tabular}

Table 3: Pilot firefighting waters properties

\begin{tabular}{ccccc}
\hline $\begin{array}{c}\text { Pilot } \\
\text { firefighting } \\
\text { water } \\
\text { denomination }\end{array}$ & $\begin{array}{c}\text { Volume } \\
(\mathrm{L})\end{array}$ & $\begin{array}{c}\text { Turbidity } \\
\text { (NTU) }\end{array}$ & $\mathrm{pH}$ & $\begin{array}{c}\text { Fluorinated } \\
\text { surfactant } \\
\text { concentration } \\
\left(\mathrm{mg} \mathrm{L}^{-1}\right)\end{array}$ \\
\hline \hline PFW1 & 17 & 27 & 8.2 & 94 \\
\hline PFW2 & 50 & 30 & 6.8 & 133 \\
\hline PFW3 & 5 & 70 & 7.5 & 144 \\
\hline
\end{tabular}

Table 4: Visual estimation of the minimal pretreatment time for PFW2. Experiments done in ${ }^{a}:$ EC1 cell; ${ }^{b}:$ EC2 cell.

\begin{tabular}{lcccccc}
\hline $\mathrm{j}\left(\mathrm{mAcm} \mathrm{cm}^{-2}\right)$ & $0.9^{a}$ & $1.2^{b}$ & $1.4^{a}$ & $1.4^{a}$ & $1.9^{a}$ & $2.5^{b}$ \\
\hline \hline $\mathrm{i}(m A)$ & 330 & 1000 & 490 & 490 & 655 & 2000 \\
\hline $\begin{array}{l}\text { Volume } \\
(m L)\end{array}$ & 500 & 3000 & 500 & 1000 & 500 & 3000 \\
\hline $\begin{array}{l}\text { Visual } \\
\text { minimal } \\
\text { time (min })\end{array}$ & 15 & 30 & 8 & 15 & 7 & 15 \\
\hline $\begin{array}{l}\text { Visual } \\
\text { minimal } \\
\text { charge }\end{array}$ & 594 & 600 & 470 & 441 & 546 & 600 \\
$\begin{array}{l}\text { loading } \\
\left(C L^{-1}\right)\end{array}$ & & & & & & \\
\hline
\end{tabular}


Table 5: Fluorinated surfactant and aluminium concentrations in bulk and whole acidified solutions after $0.45 \mu \mathrm{m} P V D F$ syringe filtration. *: Electrocoagulation of $1000 \mathrm{~mL}$ of PFW2. Other experiments were done with $500 \mathrm{~mL}$ of PFW2, ${ }^{e}$ : estimated concentrations.

\begin{tabular}{ccccccc}
\hline $\begin{array}{c}\text { Charge } \\
\text { loading } \\
\left(C L^{-1}\right)\end{array}$ & $\begin{array}{c}\mathrm{j} \\
\left(m \mathrm{~cm}^{-2}\right)\end{array}$ & $\begin{array}{c}\text { Fluorinated } \\
\text { surfactant } \\
\left(m g L^{-1}\right)\end{array}$ & $\begin{array}{c}\text { Final } \\
\mathrm{pH}\end{array}$ & $\begin{array}{c}\text { Dissolved } \\
\text { alu- } \\
\text { minium } \\
\left(m g L^{-1}\right)\end{array}$ & $\begin{array}{c}\text { Total } \\
\text { aluminium } \\
\left(m g L^{-1}\right)\end{array}$ & $\begin{array}{c}\text { Aluminium } \\
\text { current } \\
\text { efficiency }\end{array}$ \\
\hline \hline 588 & 1.4 & 40 & 7.8 & $0.7^{e}$ & 82 & $150 \%$ \\
\hline $588^{*}$ & 1.4 & 36 & 7.8 & $0.9^{e}$ & 102 & $186 \%$ \\
\hline 1170 & 1.9 & 27 & 7 & $\begin{array}{c}\text { not } \\
\text { detected }\end{array}$ & 184 & $169 \%$ \\
\hline 1176 & 1.4 & 23 & 7.5 & $0.8^{e}$ & 168 & $153 \%$ \\
\hline 1188 & 0.9 & 28 & 7.2 & $1.2^{e}$ & 130 & $117 \%$ \\
\hline 2352 & 1.4 & 4 & 8.2 & $2.6^{e}$ & 374 & $170 \%$ \\
\hline 3528 & 1.4 & 10 & 10.3 & 29 & 673 & $205 \%$ \\
\hline
\end{tabular}

Table 6: Fluorinated surfactant concentration and membrane permeability during PPFW2 reverse osmosis, 20 bar. ${ }^{a}$ : additional results from the Norwegian Institute for Air Research (NILU).

\begin{tabular}{|c|c|c|c|c|c|c|}
\hline Step & $\begin{array}{c}\text { Permeability } \\
\text { at } 25^{\circ} \mathrm{C} \\
\left(L h^{-1} m^{-2}\right. \\
\left.\text { bar }{ }^{-1}\right)\end{array}$ & $\begin{array}{l}\text { Retentat } \\
\text { volume } \\
\text { (L) }\end{array}$ & $\begin{array}{l}\text { Expected } \\
\text { retentate } \\
\text { concen- } \\
\text { tration } \\
\left(m g L^{-1}\right)\end{array}$ & $\begin{array}{c}\text { Measured } \\
\text { retentate } \\
\text { concen- } \\
\text { tration } \\
\left(m g L^{-1}\right)\end{array}$ & $\begin{array}{c}\text { Mean } \\
\text { perme- } \\
\text { ate } \\
\text { concen- } \\
\text { tration } \\
\left(\mu g L^{-1}\right)\end{array}$ & $\begin{array}{l}\text { Fluorinated } \\
\text { surfac- } \\
\text { tant } \\
\text { mass } \\
\text { balance } \\
\text { (mg) }\end{array}$ \\
\hline $\begin{array}{c}\text { Full } \\
\text { recycle }\end{array}$ & 1.033 & 5.8 & $27 \pm 5$ & $20 \pm 1$ & - & $-40 \pm 10$ \\
\hline $\begin{array}{l}\text { Concen- } \\
\text { tration }\end{array}$ & 0.914 & - & - & - & $10.47^{a}$ & - \\
\hline $\begin{array}{c}\text { Full } \\
\text { recycle }\end{array}$ & 0.921 & 3.8 & $41 \pm 11$ & $34 \pm 2$ & - & $-27 \pm 10$ \\
\hline $\begin{array}{l}\text { Concen- } \\
\text { tration }\end{array}$ & 0.779 & - & - & - & $16.39^{a}$ & - \\
\hline $\begin{array}{c}\text { Full } \\
\text { recycle }\end{array}$ & 0.760 & 2.1 & $74 \pm 33$ & $46 \pm 2$ & - & $-60 \pm 38$ \\
\hline
\end{tabular}


Table 7: Fluorinated surfactant concentrations during artificially concentrated model pilot firefighting water 2 reverse osmosis, 20 bar, full recycle, $1 \mathrm{~h}$ equilibrium after adding

\begin{tabular}{ccccc}
\hline Artificial & $\begin{array}{c}\text { Expected } \\
\text { fluori- } \\
\text { nated } \\
\text { Adding concentration } \\
\text { factor }\end{array}$ & $\begin{array}{c}\text { Measured } \\
\text { surfactant } \\
\text { in } \\
\text { retentate } \\
\left(m g L^{-1}\right)\end{array}$ & $\begin{array}{c}\text { fluori- } \\
\text { nated } \\
\text { surfactant } \\
\left(m g L^{-1}\right)\end{array}$ & $\begin{array}{c}\text { Difference } \\
(\mathrm{mg})\end{array}$ \\
\hline \hline 0 & 1 & $23 \pm 4$ & $18 \pm 1$ & $19 \pm 5$ \\
\hline 1 & 2 & $46 \pm 7$ & $46 \pm 3$ & - \\
\hline 2 & 4.4 & $100 \pm 15$ & $99 \pm 5$ & - \\
\hline 3 & 9 & $205 \pm 30$ & $218 \pm 11$ & - \\
\hline 4 & 18.2 & $417 \pm 52$ & $401 \pm 20$ & - \\
\hline
\end{tabular}




\section{References}

[1] Buncefield Incident 11 December 2005: The Final Report of the Major Incident Investigation Board, HSE Books, 2008.

[2] J. N. Israelachvili, Intermolecular and Surfaces Forces, Elsevier Science, 1991.

[3] M. Pabon, J. M. Corpart, Fluorinated surfactants: synthesis, properties, effluent treatment, Journal of Fluorine Chemistry 114 (2002) 149 - 156.

[4] E. Kissa, Fluorinated Surfactants: Synthesis, Properties, Applications, Vol. 50, Surfactant Science Series, 1994.

[5] H. F. Schröder, R. J. Meesters, Stability of fluorinated surfactants in advanced oxidation processes-a follow up of degradation products using flow injection-mass spectrometry, liquid chromatography-mass spectrometry and liquid chromatography-multiple stage mass spectrometry, Journal of Chromatography A 1082 (2005) 110-119.

[6] V. Ochoa-Herrera, R. Sierra-Alvarez, Removal of perfluorinated surfactants by sorption onto granular activated carbon, zeolite and sludge, Chemosphere 72 (10) (2008) 1588 - 1593.

[7] Q. Yu, R. Zhang, S. Deng, J. Huang, G. Yu, Sorption of perfluorooctane sulfonate and perfluorooctanoate on activated carbons and resin: Kinetic and isotherm study, Water Research 43 (4) (2009) 1150 - 1158.

[8] E. Steinle-Darling, M. Reinhard, Nanofiltration for trace organic contaminant removal: Structure, solution, and membrane fouling effects on the rejection of perfluorochemicals, Environmental Science \& Technology 42 (14) (2008) 5292-5297. 
[9] C. Tang, Q. Fu, A. Robertson, C. Criddle, J. Leckie, Use of reverse osmosis membranes to remove perfluorooctane sulfonate (pfos) from semiconductor wastewater, Environmental Science \& Technology 40 (23) (2006) 7343-7349.

[10] C. Tang, Q. Fu, C. Criddle, J. Leckie, Effect of flux (transmembrane pressure) and membrane properties on fouling and rejection of reverse osmosis and nanofiltration membranes treating perfluorooctane sulfonate containing wastewater, Environmental Science \& Technology 41 (6) (2007) 2008-2014.

[11] J. Duan, J. Gregory, Coagulation by hydrolysing metal salts, Advances in Colloid and Interface Science 100-102 (2003) 475-502.

[12] M. Y. A. Mollah, R. Schennach, J. R. Parga, D. L. Cocke, Electrocoagulation (ec) - science and applications, Journal of Hazardous Materials 84 (1) (2001) $29-41$.

[13] G. Chen, Electrochemical technologies in wastewater treatment, Separation and Purification Technology 38 (1) (2004) $11-41$.

[14] T. Picard, G. Cathalifaud-Feuillade, M. Mazet, C. Vandensteendam, Cathodic dissolution in the electrocoagulation process using aluminium electrodes., J Environ Monit 2 (1) (2000) 77-80.

[15] P. K. Holt, G. W. Barton, M. Wark, C. A. Mitchell, A quantitative comparison between chemical dosing and electrocoagulation, Colloids and Surfaces A: Physicochemical and Engineering Aspects 211 (2-3) (2002) $233-248$.

[16] M. Y. Mollah, P. Morkovsky, J. A. Gomes, M. Kesmez, J. Parga, D. L. Cocke, Fundamentals, present and future perspectives of electrocoagulation, Journal of Hazardous Materials 114 (1-3) (2004) 199 - 210. 
[17] M. Kobya, O. T. Can, M. Bayramoglu, Treatment of textile wastewaters by electrocoagulation using iron and aluminum electrodes, Journal Of Hazardous Materials 100 (1-3) (2003) 163-178.

[18] M. Zaied, N. Bellakhal, Electrocoagulation treatment of black liquor from paper industry, Journal of Hazardous Materials 163 (2-3) (2009) 995-1000.

[19] J. Ge, J. Qu, P. Lei, H. Liu, New bipolar electrocoagulationelectroflotation process for the treatment of laundry wastewater, Separation and Purification Technology 36 (1) (2004) 33 - 39.

[20] J. Trompette, H. Vergnes, On the crucial influence of some supporting electrolytes during electrocoagulation in the presence of aluminum electrodes, Journal of Hazardous Materials 163 (2-3) (2009) 1282-1288.

[21] P. K. Holt, Electrocoagulation: Unravelling and synthesising the mechanisms behind a water treatment process, Ph.D. thesis, University of Sydney. Chemical Engineering (2003).

[22] B. G. Lipták, Instrument Engineers' Handbook: Process measurement and analysis, CRC Press, 2003.

[23] M. Bennajah, Traitement des rejets industriels liquide par électrocoagulation/électroflotation en réacteur airlift, Ph.D. thesis, Institut National Polytechnique de Toulouse (2007).

[24] M. Khemis, G. Tanguy, J. Leclerc, G. Valentin, F. Lapicque, Electrocoagulation for the treatment of oil suspensions : Relation between the rates of electrode reactions and the efficiency of waste removal, Process Safety and Environmental Protection 83 (1 B) (2005) $50-57$.

[25] M. Carmona, M. Khemis, J.-P. Leclerc, F. Lapicque, A simple model to predict the removal of oil suspensions from water using the electrocoag- 
ulation technique, Chemical Engineering Science 61 (4) (2006) 1237 1246.

[26] P. Canizares, F. Martinez, J. Lobato, M. A. Rodrigo, Break-up of oilin-water emulsions by electrochemical techniques, Journal of Hazardous Materials 145 (1-2) (2007) $233-240$. 